\title{
PELATIHAN PEMBUATAN BAHAN AJAR UNTUK PEMBELAJARAN MATEMATIKA DENGAN PENDEKATAN MATEMATIKA REALISTIK INDONESIA
}

\author{
Iis Juniati Lathiifah, Fitri Apriani, Putri Cahyani Agustine \\ STKIP Muhammadiyah Bangka Belitung, Bangka Tengah, Indonesia \\ iis.juniatilathiifah@stkipmbb.ac.id
}

\begin{abstract}
Abstrak: Salah satu unsur konkrit yang sangat penting dalam upaya peningkatan kualitas sumber daya manusia adalah peningkatan mutu pendidikan. Namun kenyataannya guru kurang mengembangkan kreativitas untuk merencanakan, menyiapkan, dan membuat bahan ajar secara matang yang kaya inovasi sehingga menarik bagi siswa. Kebanyakan aktivitas pembelajaran matematika hanya menyajikan permasalahan dan rumus-rumus saja tanpa memperhatikan penanaman konsepnya. Melihat banyaknya CPNS calon guru pada tahun 2019 ini, terdapat peluang untuk merubah sistem belajar di sekolah agar lebih bervariatif. Tujuan dari kegiatan pengabdian masyarakat ini adalah untuk memberikan pemahaman dan pengalaman bagi calon guru tentang pembuatan bahan ajar mengunakan Pendekatan Matematika Realistik Indonesia (PMRI) dalam pembelajaran matematika dan mengahasilkan bahan ajar menggunakan konteks kehidupan sehari-hari. Pengabdian masyarakat ini dilakukan dalam bentuk pelatihan (workshop) yang mengedepankan praktik dengan metode on the job training dimana peserta pelatihan langsung bekerja di bawah bimbingan narasumber. Hasil kegiatan ini adalah produk bahan ajar berupa LKS menggunakan konteks kehidupan sehari-hari yang kemudian dibukukan dan diajukan Hak Ciptanya sehingga dapat digunakan oleh guru sekolah Dasar (SD). Setelah diadakan pelatihan diperoleh bahwa calon guru CPNS 2019 memiliki kemampuan yang sangat baik dan memilki berbagai ide kreatif dalam menyusun bahan ajar dengan konteks kehidupan sehari-hari.
\end{abstract}

Kata Kunci: pelatihan; bahan ajar; PMRI; CPNS 2019

\begin{abstract}
One of the essential aspects to improve the quality of human resources is to improve the quality of education. But in reality, the teachers are less creative in planning, preparing, and make rich and innovative teaching contents which attract the students. Mostly, mathematics learning activities only present problems and formulas without regard to the inculcation of the concepts. Considering the number of prospective teachers in 2019, there is an opportunity to change the learning approach in schools to be more varied. The purpose of this community service activity is to provide an understanding and experience for prospective teachers about making teaching materials using the Indonesian Realistic Mathematics Approach (PMRI) in learning mathematics and producing teaching materials using the context of everyday life. This community service is carried out in the form of workshops that prioritizes practice, employing the on the job training method in which the training participants directly work under the guidance of experts. The results of this activity are teaching material in the form of student worksheets using the context of daily life which are then recorded and submitted for copyright so that they can be used by elementary school teachers widely. After the training, it was found that pre-service teachers had very good abilities and a variety of creative ideas in compiling teaching materials in the context of daily life.
\end{abstract}

Keywords: training; learning material; PMRI; CPNS 2019

\section{Pendahuluan}

Proses pengembangan potensi manusia sepanjang hayat dimulai dari pendidikan. Salah satu unsur konkrit yang sangat penting dalam upaya peningkatan kualitas sumber daya manusia adalah peningkatan mutu pendidikan (Badri dan Riasti, 2012). Pendidikan di sekolah menjadi 
tanggung jawab guru karena guru merupakan salah satu pilar yang paling penting dalam dunia pendidikan yang berkaitan erat dengan proses pembelajaran.

Proses pembelajaran di kelas akan sukses jika guru memiliki keseriusan dalam mengatur proses pembelajaran agar tujuan dapat tercapai. Menurut Hakim (2017), guru memiliki kewajiban menyediakan sumber belajar yang tepat, cukup, serta bervariasi agar peserta didik mampu menguasai materi baik dari aspek pengetahuan, sikap, dan keterampilan sesuai tujuan pembelajaran yang telah dirumuskan oleh guru. Undang-undang Guru dan Dosen Nomor 14 Tahun 2005 pada Pasal 8 menyatakan kompetensi yang harus dimiliki guru adalah kompetensi pedagogis, kompetensi kepribadian, kompetensi sosial, dan kompetensi profesional. Dari empat kompetensi yang harus dimiliki tersebut, salah satu kompetensi inti yang wajib dimiliki oleh guru adalah mampu menyelenggarakan kegiatan pembelajaran yang mendidik dan mengembangkan materi pembelajaran yang diampu secara kreatif. Sejalan akan hal itu, Hakim (2017) juga menyatakan bahwa memberikan materi yang cukup dan sesuai dengan kebutuhan riil siswa merupakan tanggung jawab guru dimana guru wajib menyajikan materi ajar yang dapat memudahkan peserta didik untuk mempelajarinya dalam proses pembelajaran. Dari paparan di atas dapat disimpulkan bahwa guru berkewajiban mensukseskan pembelajaran di kelas dengan menyediakan sumber belajar yang tepat, mengembangkan materi yang cukup dan sesuai dengan kebutuhan siswa sehingga tujuan pembelajaran dapat terpenuhi.

Tugas guru dalam proses pembelajaran di dalam kelas adalah sebagai perencana, pemroses, dan evaluator (Purnanto \& Mahardika, 2017). Guru sebagai perencana guru diwajibkan untuk menyusun administrasi dan mempersiapkan apa saja yang dapat menunjang kegiatan pembelajaran. Guru sebagai pemroses kegiatan pembelajaran diharuskan dapat menjadi fasilitator yang baik agar proses pembelajaran berjalan dengan lancar. Sedangkan guru sebagai evaluator diharuskan melakukan penilaian terhadap seluruh proses pembelajaran yang sudah berlangsung dimulai dari menilai pencapaian kompetensi peserta didik, penyusunan laporan kemajuan hasil belajar, kemudian memperbaiki proses pembelajaran (PP No. 19 Tahun 2005). Namun kenyataannya, terlihat masih banyak guru belum dapat memilih metode pembelajaran yang sesuai dan seringkali terlihat guru sangat minim dalam penggunaan media pembelajaran (Nurhafizah, 2018). Hasil observasi yang dilakukan Zuriah, Sunaryo, \& Yusuf (2016) menyatakan bahwa masalah pengembangan diri para pendidik adalah sangat krusial dalam memajukan sistem pendidikan di Indonesia. Masalah perilaku dalam mengajar ini masih menjadi problem utama dan belum berkembang dalam diri guru/pendidik di Indonesia. Lebih lanjut Zuriah, dkk. (2016) menyatakan bahwa guru tampaknya kurang mengembangkan kreativitas untuk merencanakan, menyiapkan dan membuat bahan ajar secara matang yang kaya inovasi sehingga menarik bagi siswanya. Dan dari hasil observasi penulis terhadap beberapa orang guru Sekolah Dasar (SD) yang ada di Kota Pangkalpinang, mereka lebih memilih untuk menggunakan buku teks yang telah dikeluarkan oleh pemerintah saja karena untuk membuat bahan ajar merupakan pekerjaan yang sulit dan memakan waktu yang cukup banyak ditambah lagi sibuk membuat perangkat pembelajaran yang dituntut harus ada setiap awal semester. Padahal di dalam buku teks yang ada sekarang belum memenuhi kebutuhan riil peserta didik (Hakim, 2017). Terutama mata pelajaran matematika yang kebanyakan hanya 
menyajikan permasalahan dan rumus-rumus saja tanpa memperhatikan penanaman konsepnya.

Matematika adalah mata pelajaran yang di ajarkan pada setiap jenjang pendidikan. Salah satu ilmu dasar yang harus dikuasai oleh siswa sekolah adalah matematika karena matematika tidak dapat dipisahkan dari kehidupan sehari-hari (Apriani, 2018). Dengan kata lain, jika konsep awal matematika saja tidak dikuasai, bagaimana bisa melanjutkan ke konsep-konsep yang lainnya. Sehingga seharusnya, paradigma yang selama ini hanya sebatas pemberian materi, contoh soal, lalu pemberian soal saja dapat berubah. Guru seharusnya tidak hanya memberikan pengetahuan jadi, tetapi siswa hendaknya secara aktif membangun pengetahuan dalam pikiran mereka sendiri (Misdalina, Zulkardi \& Purwoko, 2009).

Untuk menunjang kreativitas guru inilah, maka penulis yang merupakan Dosen Pendidikan Matematika STKIP Muhammadiyah Bangka Belitung terpancing untuk dapat memberikan pelatihan bagaimana mengajarkan matematika dengan menyenangkan yang berangkat dari pembahasan soal-soal dalam kehidupan seharihari serta bagaimana membuat siswa paham, bukan hanya mengerti materi. Penulis ingin mempersiapkan alumni STKIP Muhammadiyah Bangka Belitung yang baru saja lulus seleksi Calon Pegawai Negeri Sipil (CPNS) tahun 2019 agar bisa kreatif dan inovatif dalam pembelajaran khususnya matematika. Karena mempersiapkan guru dengan baik adalah hal pertama yang harus dilakukan pada sistem pendidikan.

Melihat peluang yang ada ini, maka kami tertarik mengadakan pelatihan pembuatan bahan ajar dengan menggunakan Pendekatan Matematika Realistik Indonesia (PMRI) untuk guru SD agar guru mempunyai media pendukung untuk membantu dalam pembelajaran. Bahan ajar dapat diartikan sebagai bahan-bahan atau materi pelajaran yang disusun secara lengkap dan sistematis berdasarkan prinsip-prinsip pembelajaran yang digunakan guru dan siswa dalam proses pembelajaran (Sungkono, 2003)

PMRI dipilih karena pendekatan pembelajaran matematika yang sesuai untuk pemahaman konsep siswa adalah pendekatan pembelajaran matematika realistik karena PMRI adalah pendekatan pembelajaran matematika yang menyenangkan dan memanfaatkan lingkungan sebagai sumber belajar (Misdalina, dkk., 2009). Berbagai hasil penelitian (Zulkardi \& Putri, 2010; Putri, 2011; Feriana, 2016; Bustang, Zulkardi, Darmawijoyo, 2013; Marion, dkk., 2015; dan Apriani, Zulkardi, \& Darmawijoyo, 2017) menunjukkan bahwa pendekatan pembelajaran matematika realistik cukup efektif untuk meningkatkan pemahaman konseptual siswa dan dapat digunakan untuk meningkatkan kemampuan pemecahan masalah. Namun, pendekatan pembelajaran ini belum banyak diterapkan guru karena berbagai kendala.

Beberapa hal yang menjadi kendala dalam pembelajaran matematika adalah guru kurang menyadari akan pentingnya menyusun bahan ajar yang sesuai dengan kebutuhan, manfaat bahan ajar dalam penyiapan perangkatpembelajaran dan pelaksanaan pembelajaran, Guru kurang memahami mekanismedan teknis menyusun bahan ajar yang benar. Oleh karena itu, untuk mempersiapkan alumni yang baru dilantik CPNS tahun 2019, STKIP muhammadiyah bangka belitung ingin memberikan pelatihan tentang pembuatan bahan ajar menggunakan 
Pendekatan Matematika Realistik Indonesia (PMRI). Bahan ajar yang dibuat berupa LKS dengan kriteria sebagai berikut:

a. LKS disusun dari yang konkrit ke abstrak sesuai dengan tujuan pembelajaran dan berdasarkan konteks kehidupan siswa.

b. Bahan ajar yang disusun satu materi matematika untuk satu kompetensi dasar.

c. Keluasan dan kedalaman bahan ajar disusun dengan memperhatikan potensipeserta didik, misalnya peserta didik yang belajarnya cepat atau lambat, pesertadidik yang memiliki motivasi tinggi dan rendah.

Tujuan dari kegiatan pelatihan pembuatan bahan ajar ini ada dua, yang pertama adalah untuk memberikan pemahaman dan pengalaman bagi guru Calon Pegawai Negeri Sipil tentang pembuatan bahan ajar mengunakan Pendekatan Matematika Realistik Indonesia (PMRI) dalam pembelajaran matematika. Yang kedua tujuannya adalah untuk mengahasilkan bahan ajar menggunakan konteks kehidupan sehari-hari sehingga kemudian dapat dibukukan dan diurus Hak Cipta agar bisa digunakan oleh guru SD.

Adapun manfaat dari kegiatan ini adalah untuk menambah bekal kreativitas bagi guruguru dalam mengajarkan matematika yang berkesan bagi anak didik, yakni dengan PMRI. Disamping itu juga, bahan ajar berupa LKS yang peserta hasilkan dapat digunakan dan diterapkan di sekolah masing-masing serta dapat pula digunakan oleh teman-teman guru SD lainnya.

\section{Metode}

Pengabdian masyarakat ini dilakukan dalam bentuk pelatihan (workshop) yang mengedepankan praktik dengan metode on the job tarining dimana peserta pelatihan langsung bekerja di tempat di bawah bimbingan narasumber. Prosedur pelaksanaan kegiatan adalah workshop dan pelatihan bahan ajar PMRI, pendampingan dalam pelaksanaan pelatihan bahan ajar, dan refleksi hasil pelatihan \& pendampingan pelatihan bahan ajar. Sedangkan metode yang digunakan dalam pengabdian ini adalah:

1. Ceramah

Materi yang diberikan adalah pemahaman mengenai bahan ajar (LKS), alur pembuatan bahan ajar, PMRI, dan konteks.

2. Diskusi

Pada tiap materi yang disampaikan,peserta dapat berdialog danberdiskusidengan tim pengabdian mulai dari analisis Standar Kompetensi (SK), Kompetensi Dasar (KD), dan Indikator, penentuan konteks yang akan digunakan, dan membuat peta konsep bahan ajar.

3. Bimbingan dan Praktek

Peserta diminta untuk membuat bahan ajar sesuai konteks yang telah ditentukan. Bahan ajar yang dibuat merupakansyarat untuk memperoleh sertifikat peserta. 
Tahapan pelaksanaan pengabdian adalah sebagai berikut:

1. Persiapan. Pada tahap ini, penulis melakukan studi pustaka tentang bahan ajar, studi pustaka mengenai Pendekatan Matematika Realistik (PMRI), studi pustaka jurnal bahan ajar Pendekatan Matematika Realistik (PMRI), dan desain konsep pelatihan.

2. Pelaksanaan. Pada tahap ini, penulis melakukan berbagai kegiatan yaitu memberikan pemahaman mengenai Bahan Ajar (LKS) dengan Pendekatan Matematika Realistik (PMRI) dan berbagai bentuk konteks, menganalisis SK, KD, dan Indikator, serta penentuan konteks yang sesuai untuk KD yang dipilih. Kemudian peserta diminta untuk membuat bahan ajar (LKS) dengan SK, KD, Indikator, dan konteks yang telah dipilih.

3. Evaluasi. Pada tahap ini, kegiatan yang dilakukan adalah pleno tentang bahan ajar yang telah dibuat kemudian peserta melaporkan hasil dari penerapan LKS yang telah dibuat.

Kegiatan pengabdian masyarakat ini dilaksanakan pada tanggal 10-11 April 2019 di STKIP Muhammadyah Bangka Belitung. Durasi kegiatan pengabdian selama dua hari sebanyak 960 menit (Pukul 08.00 - 16.00 WIB) dengan rincian 840 menit pelatihan dan 120 menit ISHOMA. Kegiatan pelatihan ini melibatkan alumni STKIP Muhammadiyah Bangka Belitung yang dilantik sebagai CPNS tahun 2019.

\section{Hasil dan Pembahasan}

Kegiatan pelatihan pembuatan bahan ajar ini dilaksanakan di Ruang perkuliahan lantai dua pada Gedung Rektorat Kampus Sekolah Tinggi Keguruan dan Ilmu Pendidikan Muhammadiyah Bangka Belitung. Pelatihan berlangsung selama dua hari yakni pada tanggal 10 dan 11 April 2019 dari pukul 08.00 WIB sampai dengan pukul 16.00 WIB. Adapun peserta yang mengikuti kegiatan pelatihan adalah alumni STKIP Muhammadiyah Bangka Belitung jurusan PGSD yang baru saja dilantik menjadi CPNS tahun 2019 di lingkungan daerah Provinsi Kepulauan Bangka Belitung. Kegiatan ini juga merupakan salah satu bentuk bimbingan lanjutan dari para Dosen STKIP Muhammadiyah Bangka Belitung yang didedikasikan untuk kegiatan kampus, agar para alumni mendapat pendidikan dan pengetahuan yang matang sebelum mereka menunaikan tugasnya sebagai abdi negara, juga merupakan suatu bentuk rasa syukur dan bangga institusi akan keberhasilan para alumninya.

Berdasarkan tujuan dilaksanakannya kegiatan pelatihan ini, maka pemahaman tentang pembuatan bahan ajar serta pentingnya menumbuhkan sikap kreatif pada diri alumni menjadi landasan utama yang harus dicapai. Oleh sebab itu, pada hari pertama pelatihan, pemateri memberikan wawasan kepada peserta tentang apa itu bahan ajar PMRI, apa saja jenis bahan ajar dan contohnya. Melalui pemaparan dengan system sharing dan berdiskusi, banyak sekali pertanyaan-pertanyaan yang diajukan peserta pada forum diskusi. Ada peserta yang bertanya mengenai contoh dan jenis bahan ajar adapula yang membawa beberapa contoh LKS yang selama ini mereka gunakan.

Dari kegiatan sharing dan diskusi ini, terlihat sekali antusias peserta pelatihan untuk memahami apa itu bahan ajar. Ditambah dengan peserta pelatihan yang memang masih muda 
serta baru beberapa bulan menimba pengalaman menjadi seorang guru, antusias untuk belajar sangat kental terasa. Berikut ditampilkan foto kegiatan pelatihan pada gambar 1.

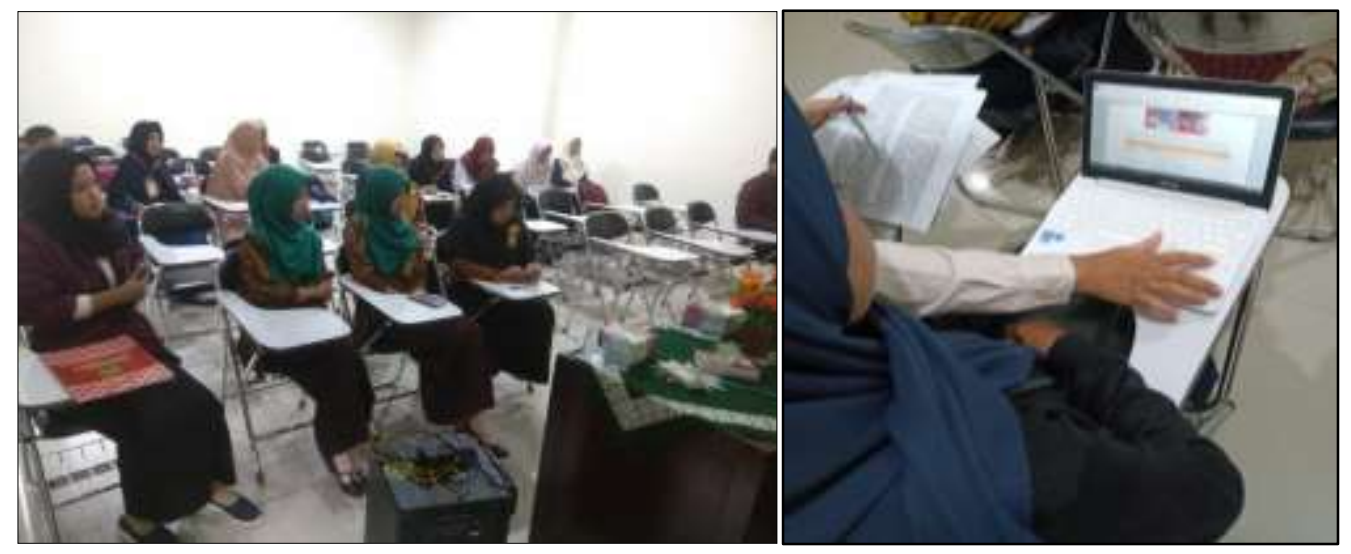

Gambar 1. Peserta Kegiatan Pelatihan

Hal kedua yang menjadi perhatian pemateri adalah pemahaman peserta tentang PMRI (Pembelajaran Matematika Realistik Indonesia). Dari 20 peserta pelatihan, hanya satu peserta yang sudah mendengar dan sedikit paham mengenai PMRI. Selebihnya masih belum tahu dan belum pernah mendengar istilah PMRI. Adapun mengenai macam-macam bahan ajar, semua peserta sudah cukup paham bagaimana bentuk dan cara pembuatan bahan ajar. Hanya saja, banyak dari peserta yang belum mempunyai pengalaman membuat bahan ajar. Oleh karena itu, pada pelatihan ini pemateri sangat menonjolkan pemahaman apa itu PMRI dan bagaimana membuat bahan ajar dengan PMRI.

PMRI masih belum dikenal secara luas oleh para guru maupun pendidik di Bangka Belitung. Oleh karena itu, pemateri sangat tertarik untuk mengenalkan PMRI agar menjadi salah satu bahan atau pendekatan dalam memahamkan matematika kepada peserta didik. PMRI dirasa cocok digunakan pada peserta didik tingkat Sekolah Dasar karena pendekatannya berangkat dari hal nyata dalam kehidupan dan keseharian siswa.

PMRI merupakan suatu pendekatan pembelajaran matematika realistik yang cukup efektif untuk meningkatkan pemahaman konsep peserta didik. Menggunakan model dan konteks merupakan beberapa dari karakteristik PMRI. Hal inilah yang menjadikan PMRI menarik bagi siswa. Konteks yang digunakan dalam pembelajaran sangat membantu peserta didik dalam mengingat dan memahami materi. Karena melalui konteks, siswa dapat menggali pemahaman kemudian menuangkannya ke dalam bentuk model matematika yang abstrak.

Pada kegiatan pelatihan ini, pemateri memberikan materi pembuatan bahan ajar berbentuk Lembar Kegiatan Peserta Didik (LKPD). Hal ini dianggap tidak terlalu sulit dipahami peserta dan waktu pembuatannya tidak terlalu lama, dibandingkan dengan buku atau modul. Dengan LKPD juga diharapkan peserta dapat fokus mengembangkan materi tertentu sehingga materi tersebut kuat melekat pada pemahaman peserta didik. Maka dari itu, sebelum kegiatan pelatihan berlangsung, peserta pelatihan telah diminta untuk membawa silabus atau RPP yang mereka gunakan di sekolah. Dengan Silabus dan RPP ini, peserta dapat langsung memikirkan materi apa yang akan mereka buatkan LKPD nya, dan cocok dengan konteks yang mereka pikirkan. 
Salah satu bahan ajar yang telah disiapkan, dan berdasarkan hasil penelitian terbaru dari pemateri, disajikan sebuah LKPD materi operasi hitung bilangan bulat. Disana pemateri jelaskan apa saja konteks yang digunakan, antara lain yakni konteks tangga Wisma Menumbing dan konteks otak-otak. Wisma menumbing merupakan bangunan bersejarah yang terletak pada Kota Muntok, Bangka Barat. Melalui konteks tangga pada bangunan Wisma tersebut, pemateri meminta siswa untuk mengurutkan bilangan mulai dari tangga bagian bawah yang disana telah ditulis dengan angka kecil, yaitu negatif tujuh hingga lanjut ke bilangan 0 dan paling tinggi terdapat bilangan positif 7 . Pengurutan bilangan ini dilakukan dengan cara naik satu angka sebanyak satu tangga.

Adapun pada materi operasi hitung campuran digunakan konteks otak-otak, dimana semua orang kenal dan tahu apa itu otak-tak, bahkan anak SD pun sangat dekat sekali dengan otakotak. Dengan konsep jual beli makanan otak-otak, disajikan bagaimana penjumlahan dan pengurangan dapat dilakukan dengan cara menambah dan mengurangi jumlah otak-otaknya. Karena materi ini fokus kepada operasi hitung bilangan, maka yang dihitung adalah berapa buah otak-otaknya. Melalui pemaparan contoh langsung LKPD dengan konteks otak-otak dan konteks lainnya yang merupakan Budaya Bangka Belitung, diharapkan peserta dapat langsung memikirkan konteks apa yang menurut mereka dapat dikembangkan lagi.

Sebelum menentukan konteks, peserta diminta untuk membaca silabus maupun RPP yang sudah mereka bawa sesuai dengan materi yang mereka akan ajarkan dikelas, karena setiap peserta merupakan guru yang ditugaskan pada kelas yang berbeda-beda. Peserta diminta untuk mencari konteks yang sesuai untuk digunakan dalam pemahaman materi yang telah mereka pilih. Namun, yang harus dipertimbangkan adalah dikenal atau tidaknya konteks yang akan mereka jadikan materi. Misalnya jika ingin menggunakan konteks permainan, makan permainan tersebut haruslah merupakan permainan dengan nama daerah bangka, dan permainan yang sering atau banyak dikenal oleh masyarakat, terutama anak-anak itu sendiri. Ketika peserta sudah dapat menentukan konteks yang sesuai dengan materi tertentu pada mata pelajaran matematika, barulah peserta diminta menentukan Kompetensi Dasar yang akan diambil, kemudian menentukan indikator-indikator apa saja yang ada di dalamnya.

Pada sesi ini, banyak dilakukan sharing antara peserta dan pemateri. Hal ini agar lebih memudahkan peserta dalam memahami apa itu konteks dan apa saja yang dapat dijadikan konteks. Selama kurang lebih 180 menit, peserta diminta langsung menuangkan ide yang telah mereka dapat untuk dijadikan konteks dalam pembelajaran. Pada sesi siang ini, kegiatan pelatihan terasa lebih menarik dan menyenangkan, karena peserta dapat langsung membuat bagan LKPD yang telah mereka bayangkan sebelumnya. Pertemuan pada hari pertama ditutup dengan berbagai permasalahan yang timbul, baik itu bagaimana membuat langkah pada LKPD, bagaimana cara menentukan indikator, dan masih beragam pertanyaan yang muncul. Namun selain permasalahan, pada pertemuan pertama, peserta telah banyak mendapatkan pelajaran apa itu bahan ajar PMRI, bagaimana memilih konteks, bagaimana konteks harus dapat dipahami oleh seluruh peserta didik. Sehingga pada pertemuan pertama, peserta telah memiliki bekal tentang apa itu bahan ajar PMRI dan bagimana karakter peserta didik mereka masing-masing untuk mengerjakan bahan ajar yang akan mereka buat. 
Pada hari berikutnya semua peserta dituntut untuk menyelesaikan LKPD yang telah mereka mulai. Semakin banyak peserta yang berkonsentrasi menyelesaikan LKPD nya, namun tidak seditkit peserta yang terus bertanya mengenai konteks yang mereka gunakan, bagaimana memanfaatkan konteks tersebut, dan berbagai permasalahan lainnya. Namun sebelum istirahat siang, hampir semua peserta telah menyelesaikan LKPD yang mereka buat. Berikut pada gambar 2 ditampilkan salah satu contoh LKPD yang berhasil dibuat peserta dengan materi menghitung rata-rata suatu kelompok data.

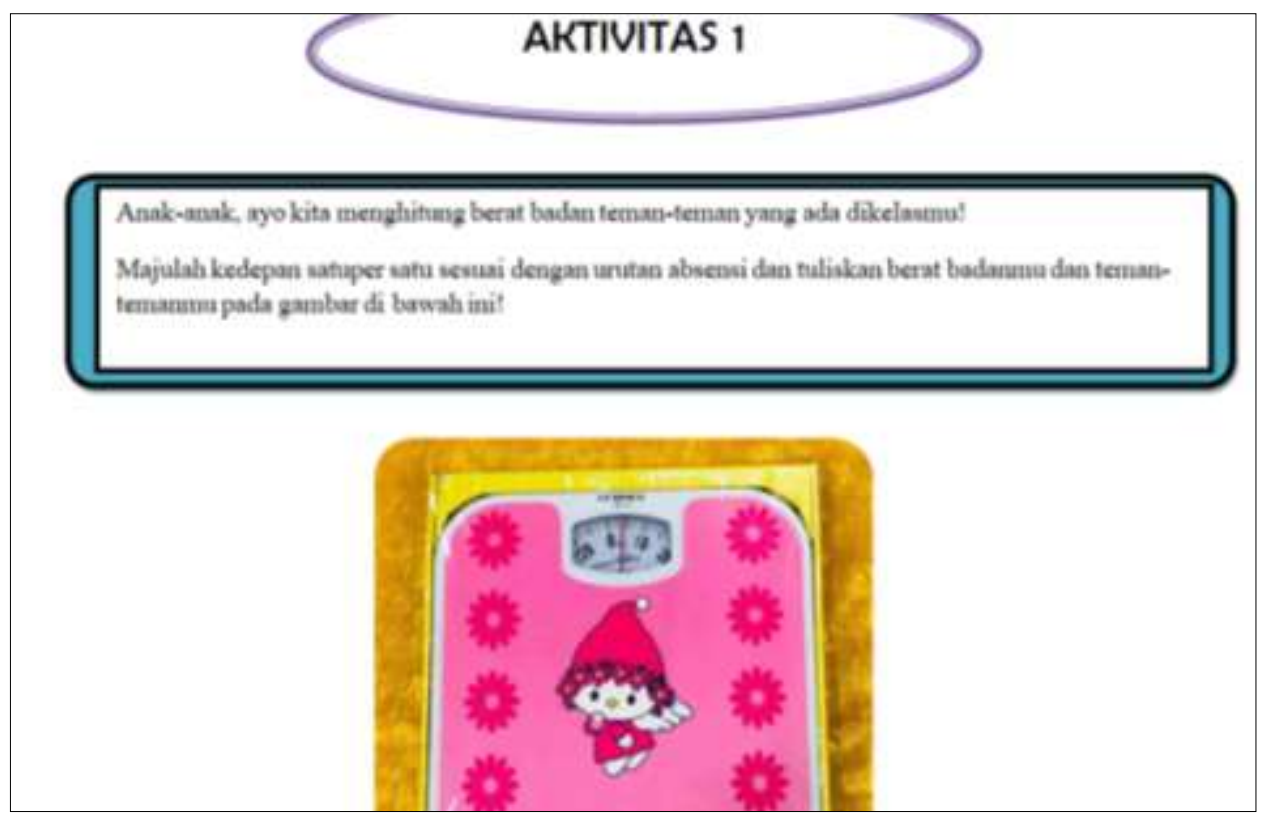

Gambar 2. Contoh LKPD peserta

Salah satu peserta membuat LKPD dengan konteks timbangan berat badan. Disana peserta membuat lembar kegiatan matematika pada materi menghitung rata-rata. Salah satu bahan yang akan dihitung adalah berat badan siswa pada kelas tersebut. Sehingga peserta membuat lembar kerja yang didalamnya peserta didik akan mengukur setiap berat badan dalam satu kelas, menggunakan timbangan digital berat badan. Setelah didapat hasil dari semua berat badan peserta didik, barulah kemudian menjumlahkan seluruh berat badan siswa dan membaginya dengan jumlah peserta didik. Dari pengalaman nyata seperti ini diharapkan peserta didik akan paham secara mendalam tetang menentukan rata-rata. Oleh sebab itu, LKPD yang dibuat harus menarik dan menggunakan kata-kata yang baku serta tidak membingungkan bagi siswa.

Selanjutnya dilaksanakan pemaparan hasil LKPD yang telah peserta buat. Pada kegiatan ini, banyak masukan yang didapat sehingga peserta dapat segera memperbaiki LKPDnya sesuai saran untuk nantinya disatukan dan dibukukan. Pemaparan sangat bermanfaat agar LKPD yang dibuat dapat dievaluasi dan diuji coba, apakah sudah sesuai dengan karakteristik siswa. Pada akhir sesi pelatihan dilakukan pengisian angket tentang seberapa bermanfaatnya kegiatan pelatihan seperti ini dilaksanakan. 
Berdasarkan indikator keberhasilan dari pelaksanaan PPM tentang Pelatihan Pembuatan Bahan Ajar Menggunakan Pendekatan Matematika Realistik Indonesia (PMRI) untuk CPNS PGSD 2019 Alumni STKIP Muhammadiyah Bangka Belitung didapat hasil bahwa 100\% peserta berhasil membuat bahan ajar dengan pendekatan PMRI pada satu sub pokok bahasan yang mereka kuasai. Bahkan terdapat $25 \%$ peserta yang berhasil membuat bahan ajar dalam satu bab materi pelajaran. Indikator keberhasilan kegiatan pelatihan dari segi proses dapat dilihat dari hasil evaluasi yang didasarkan pada taraf respons peserta mengenai kebermanfaatan kegiatan pelatihan yang diikutidengan empat kategori, dimana ada $73 \%$ yang memberi respon sangat bermanfaat dan terdapat $27 \%$ yang memberi respon bermanfaat sebagaimana dapat dilihat pada tabel berikut.

Tabel 1. Respons Peserta Mengenai Kebermanfaatan Kegiatan Pelatihan

\begin{tabular}{cccc}
\hline No & Interval & Kategori & Persentasi \\
\hline 1 & $86 \%-100 \%$ & Sangat Bermanfaat & $73 \%$ \\
\hline 2 & $66 \%-85 \%$ & Bermanfaat & $27 \%$ \\
\hline 3 & $36 \%-65 \%$ & Kurang Bermanfaat & $0 \%$ \\
\hline 4 & $0 \%-35 \%$ & Tidak Bermanfaat & $0 \%$ \\
\hline
\end{tabular}

Kebermanfaatan kegiatan ini juga dilihat dari bahan ajar yang peserta hasilkan. Dimana LKS yang telah peserta buat dapat dibukukan dan dibuat hak ciptanya, sehingga dapat disebarluaskan dan digunakan oleh teman-teman guru SD. Namun sebelum pengurusan hak cipta ini, pemateri telah melaksanakan uji validasi terlebih dahulu kepada semua LKS yang dihasilkan melalui tiga orang reviewer ahli yakni Ayen Arsisari, M.Pd. sebagai ahli bidang Matematika, Sasih Karnita Arafatun M.Pd. sebagai ahli bidang Bahasa dan Susilawati, S.Pd. sebagai ahli bidang Konstruk. Berdasarkan hasil review tersebut dinyatakan bahwa sebanyak $30 \%$ bahan ajar berhak disebarluaskan dengan sedikit perbaikan, pada penggunaan bahasa sehingga dapat langsung dipahami siswa. Adapun $70 \%$ dinyatakan layak namun wajib direvisi terlebih dahulu, baik pada gambar, ilustrasi maupun pada penggunaan bahasa, dan tulisan.

\section{Kesimpulan}

Setelah kegiatan pengabdian masyarakat dilakukan, peserta mendapatkan pemahaman dan pengalaman dalam pembuatan bahan ajar mengunakan Pendekatan Matematika Realistik Indonesia (PMRI) pada pembelajaran matematika. Kegiatan juga menghasilkan produk bahan ajar berupa LKS yang menggunakan konteks kehidupan sehari-hari sehingga kemudian dapat dibukukan dan diurus Hak Cipta sehingga bisa digunakan oleh guru SD. Kemudian dari segi hasil produk, yakni berupa LKS yang dihasilkan dapat dikategorikan baik dari segi konten, konstruk, dan bahasa. Indikator keberhasilan kegiatan pelatihan ini juga tampak dari hasil respon peserta mengenai kebermanfaatan kegiatan pelatihan yang diikuti, dengan yang rata-rata menyatakan sangat bermanfaat. Secara keseluruhan, pelatihan bahan ajar telah berhasil menumbuhkan jiwa kreatif alumni yang sedang menjadi calon guru, dan membuat mereka lebih bersemangat dalam pembelajaran, bukan hanya mengajar tetapi juga belajar dari situasi masing-masing peserta didik yang mereka temui. 


\section{Referensi}

Apriani, F. (2018). Kesalahan Mahasiswa Calon Guru SD dalam Menyelesaikan Soal Pemecahan Masalah Matematika. Journal of Mathematics Science and Education, 1(1), 102-117.

Apriani, F., Zulkardi, \& Darmawijoyo. (2017). Pendekatan PMRI Membantu Siswa Berpikir Kritis pada Materi Sistem Persamaan Linear di Kelas X. Seminar Nasional dan Workshop Matematika dan Pendidikan Matematika "Menjawab Tantangan Abad 21 Melalui 4C's dengan PMR" STKIP PGRI Sumatera Barat, 111-122. Padang: STKIP PGRI Sumatera Barat Press.

Badri, N., \& Riasti, B. K. (2012). Pembuatan Media Pembelajaran Interaktif Pada Smk Negeri Tiga Jepara Dengan Materi Power Point 2007. Speed-Sentra Penelitian Engineering dan Edukasi, 4(1): 73-78

Bustang, B., Zulkardi, Z., Darmawijoyo, D., Dolk, M. L. A. M., \& Van Eerde, H. A. A. (2013). Developing a local instruction theory for learning the concept of angle through visual field activities and spatial representations. International Education Studies, 6(8), 58-70.

Feriana, O., \& Putri, R. I. I. (2016). Desain Pembelajaran Volume Kubus dan Balok Menggunakan Filling dan Packing di Kelas V. Jurnal Kependidikan: Penelitian Inovasi Pembelajaran, 46(2), 149-163.

Hakim, D. L. (2017). Pelatihan Pembuatan Bahan Ajar Matematika Media Prezi. UNES Journal of Community Service, 2(2), 157-163.

Marion, M., Zulkardi, Z., \& Somakim, S. (2015). Desain Pembelajaran Pola Bilangan Menggunakan Model Jaring Laba-Laba di SMP. Jurnal Kependidikan: Penelitian Inovasi Pembelajaran, 45(1), 44-61.

Misdalina, M., Zulkardi, Z., \& Purwoko, P. (2009). Pengembangan Materi Integral untuk Sekolah Menengah Atas (SMA) Menggunakan Pendekatan Pendidikan Matematika Realistik Indonesia (PMRI) di Palembang. Jurnal Pendidikan Matematika, 3(1), 61-74.

Nurhafizah, N. (2018). Pelatihan Pembuatan Media Pembelajaran Anak Usia Dini menggunakan Bahan Sisa. Early Childhood: Jurnal Pendidikan, 2(2b), 44-53.

Peraturan Pemerintah No. 19 Tahun 2005 tentang Standar Nasional Pendidikan

Purnanto, A. W., \& Mahardika, A. (2017). Pelatihan Pembuatan Soal Interaktif Dengan Program Wondershare Quiz Creator Bagi Guru Sekolah Dasar di Kota magelang. Warta LPM, 19(2), 141148.

Putri, R. I. (2011). Professional Development of Mathematics Primary School Teacher in Indonesia Using Lesson Study and Realistic Mathematics Education Approach. Lymasol, Cyprus: Proceeding of International Congress for school Effectiveness and Improvement (ICSEI).

Sungkono. (2003). Pengembangan Bahan Ajar. Yogyakarta: FIP UNY.

Undang-undang Guru dan Dosen Nomor 14 Tahun 2005 tentang Guru dan Dosen

Zulkardi, Z., Putri, I. (2010). Pengembangan blog support untuk membantu siswa dan guru matematika Indonesia belajar pendidikan matematika realistic Indonesia (PMRI). Jurnal inovasi perekayasa pendidikan (JIPP), 2(1), 1-24.

Zuriah, N., Sunaryo, H., \& Yusuf, N. (2016). IbM guru dalam pengembangan bahan ajar kreatif inovatif berbasis potensi lokal. Jurnal Dedikasi, 13, 39-49. 